International Journal of Agriculture, Environment and Bioresearch

Vol. 06, No. 01; 2021

ISSN: $2456-8643$

\title{
THE EVALUATION OF CONFECTIONERY SUNFLOWER (Helianthus Annuus L.) CULTIVARS AND POPULATIONS FOR YIELD AND YIELD COMPONENTS
}

\author{
Ismail Demir \\ Kırşehir Ahi Evran University, Faculty Of Agriculture,department Of Field Crops, Kırşehir, Turkey \\ https://doi.org/10.35410/IJAEB.2021.5612
}

\begin{abstract}
This study was performed to determine yield and some quality components of confectionary sunflower (Helianthus annuus L.) populations and cultivars in 2015-2016 under rainfed condition of semi-arid climate zone. Experiments were carried out in the Randomized Complete Blocks Design with three replications. Plant height, head diameter, hull ratio, seed yield per plant, thousand seed weight, seed yield and crude oil content were investigated. The highest seed yield and head diameter were $3791.39 \mathrm{~kg}$ ha-1and $20.35 \mathrm{~cm}$ from Çigdem- 1 cultivar, seed yield per plant was $127.51 \mathrm{~g}$ from Hamit population, thousand seed weight was $125.93 \mathrm{~g}$ from Elbistan population, seed hull ratio was $54.37 \%$ from Elbistan population, oil content was $34.24 \%$ from ÇRZ 13-7 variety and plant height $161.33 \mathrm{~cm}$ from Inegöl population. Rainfed agriculture condition especially in semi-arid climate zone, rainfall and temperature in growing period have important role on seed yield. It has been observed that local populations of confectionary sunflower generally retain their yield capabilities better when stress conditions increase.
\end{abstract}

Keywords: Confectionery Sunflower, Population, Seed Yield, Rainfed Condition.

\section{INTRODUCTION}

Sunflower is an important oilseed plant to meet the vegetable oil need. In addition to the production of sunflower for oil, sunflower varieties for confectionary are also included in production. Confectionery Non-oil seed sunflower generally has a relatively thick hull that remains loosely attached to the kernel, permitting more complete dehulling[1]. Seed of the confectionary sunflower generally is larger than that of the oilseed types and has a lower oil percentage and dehulled kernel ratio. The use of confectionary sunflower seeds has a long and rich tradition in Russia, Turkey and Ukraine. The favoured seed colour of confectionary hybrids in Turkey is white with grey stripes, while in Balkan countries such as Serbia, Bulgaria, Moldova, and Romania, as well as Russia black seeds are preferred[2-4]. Confectionary non-oil sunflower seed types can be black, white, black with white stripes, or colourful and significantly larger than the oil-type sunflower seeds. Day by day, depending on the consumption, the cultivation of confectionary sunflower also increases. Confectionary sunflower production in Turkey is mostly done with genotypes referred to by name if the local population. Some of them are in the form of village populations named Alaca, Kırıkkale, Denizli, Cyprus, Maraş, Haymana ala, Aksaray. After 2008, the varieties named Çiğdem 1 and Palancı 1 were also developed, but they could not find a place in production widely. In Turkey, the most common types of Inegöl 
Alain (registered in 2013) production are performed[5]. Additionally, confectionary sunflower data both for production and consumption cannot be found in most national or international organization statistics in the world. Oil seed and confectionary sunflower cultivation areas and production statistical data in Turkey are collected separately. In 2019, the sunflower cultivation area for confectionary was 76.5 thousand ha, while the cultivation area for oil seed sunflower was 675 thousand ha. Production is approximately 2 million tons for oil seed sunflower and 150 thousand tons for confectionary sunflower. In some cities of Turkey (Kayseri, Kahramanmaraş, Denizli) only confectionary sunflower is cultivated. However, confectionary sunflower production is not enough for Turkey consumption and domestic needs are supplied by importing similar type $[4,5]$.

This study was performed to determine yield and some quality components of confectionary sunflower (Helianthus annuus L.) populations which was collecting from different regions of Turkey and to compare all genotypes performance in semi-arid climate zone under rainfed condition. The introduction of the paper should explain the nature of the problem, previous work, purpose, and the contribution of the paper. The contents of each section may be provided to understand easily about the paper.

\section{MATERIAL AND METHODS}

This study was conducted in Research Farm of Agricultural Faculty of Kurşehir Ahi Evran University in 2015 and 2016. This experimental field in Kırşehir province is located at $39.15^{\circ}$ Northern latitude and $34.11^{\circ}$ Eastern longitude at 1014 meters above sea level. Experimental soil of field has clayed loam texture, alkaline character, calcareous, non-saline, has certain amount of available phosphorus concentration, rich in potassium content, poor in organic matter and nitrogen classes as described by Kacar [6] (Table 1).

Table 1. Soil properties of the experimental field at $0-30 \mathrm{~cm}$ depth

\begin{tabular}{|l|l|l|l|l|l|l|l|}
\hline $\begin{array}{l}\text { Saturatio } \\
\mathrm{n} \%\end{array}$ & $\mathrm{pH}$ & $\begin{array}{l}\mathrm{EC} \\
(\mathrm{mmhos} / \mathrm{cm})\end{array}$ & $\begin{array}{l}\text { Tuz } \\
(\%)\end{array}$ & $\begin{array}{l}\text { Absorbabl } \\
\text { e P }(\%)\end{array}$ & $\begin{array}{l}\text { CaCO } \\
3(\%)\end{array}$ & $\begin{array}{l}\text { Absorbabl } \\
\text { e K (ppm) })\end{array}$ & $\begin{array}{l}\text { Organic } \\
\text { matter } \\
(\%)\end{array}$ \\
\hline 55 & 7,59 & 0,58 & 0,021 & 0,19 & 21,8 & 63,78 & 1,39 \\
\hline
\end{tabular}

The meteorological data for the research period of the two years were collected from Kırşehir Meteorology Station located about $1.5 \mathrm{~km}$ away from the Research Farm. The experimental site was located in semi-arid climate zone with continental climate characteristics and limited rainfall distribution having peaks usually in period of December to June. Dry period often referred to as after June to November. Weather data of experimentation in 2015 and 2016 are presented in Tables 2. The months of June $(161.4 \mathrm{~mm})$ in 2015 and May $(95.8 \mathrm{~mm})$ in 2016 were the wettest months during the research periods. Total rainfall of growing period of research years were $260.80 \mathrm{~mm}$ and $183.50 \mathrm{~mm}$ in 2015 and 2016 respectively. Both 2015 and 2016 were warmer than long term monthly average temperature and after May to September in 2016 were hottest months based on mean atmospheric temperature. Relative humidity values, however, ranged 
Vol. 06, No. 01; 2021

ISSN: $2456-8643$

between $42.5 \%$ (July 2016) and 66.8\% (June 2015) and 2016 growing period was dryer then 2015 as shown in Table 2.

Table 2. Meteorological data of the study area

\begin{tabular}{|c|c|c|c|c|c|c|c|c|c|}
\hline \multirow[b]{2}{*}{ Months } & \multicolumn{3}{|c|}{ Mean Temperature $\left({ }^{\circ} \mathrm{C}\right)$} & \multicolumn{3}{|c|}{ Relative Humidity (\%) } & \multicolumn{3}{|c|}{ Precipitation (mm) } \\
\hline & $\begin{array}{l}1970- \\
2020\end{array}$ & 2015 & 2016 & $\begin{array}{l}1970- \\
2018\end{array}$ & 2015 & 2016 & $\begin{array}{l}1970- \\
2018\end{array}$ & 2015 & 2016 \\
\hline April & 10.85 & 8.80 & 13.80 & 63.29 & 66.2 & 47.4 & 42.44 & 26.80 & 23.80 \\
\hline May & 15.39 & 16.0 & 14.90 & 60.80 & 58.1 & 63.7 & 44.30 & 39.20 & 95.80 \\
\hline June & 19.74 & 18.4 & 21.00 & 54.00 & 66.8 & 53.0 & 36.80 & 161.4 & 16.10 \\
\hline July & 23.34 & 23.0 & 24.20 & 48.10 & 47.0 & 42.5 & 6.80 & 20.60 & 5.80 \\
\hline August & 23.43 & 24.8 & 25.70 & 48.40 & 47.5 & 43.8 & 4.90 & 11.80 & \\
\hline Septembe & 19.10 & 23.0 & 18.40 & 53.10 & 40.8 & 48.2 & 11.60 & 1.00 & 42.00 \\
\hline Mean & 18.60 & 19.0 & 19.70 & 54.60 & 54.4 & 49.8 & & & \\
\hline Total & & & & & & & 146.84 & 260.8 & 183.5 \\
\hline
\end{tabular}

The experimental sites were ploughed twice and harrowed once before marking out the plots. Ten confectionary sunflower genotypes and population (Palancı-1, TTAE-ÇRZ-13-4, TTAEÇRZ-13-6, TTAE-ÇRZ-13-7, TTAE-ÇRZ-13-9, TTAE-ÇRZ-13-10, Çiğdem 1, Elbistan, Hamit and Inegöl) were evaluated regarding their yield and yield parameters. At each sowing date, seeds of the test varieties were sown at as pacing of $70 \mathrm{cmx} 40 \mathrm{~cm}$ which corresponded to 35,000 plants ha-1 in the second week of April (10 April 2016 and 12 April 2017). Three seeds of the test varieties were sown per hole and later thinned to one plant per stand at stage of 4- 6 true leaf. Each experimental plot consisted of six rows $4 \mathrm{~m}$ in length and measured $4.2 \mathrm{mx} 4 \mathrm{~m}(16.8 \mathrm{~m} 2)$. No agro-chemicals were used during both experiments in order to simulate the usual practice of the farmers and less environmental damage. The crop was grown under rain-fed conditions which is the usual practice of the semi-arid climate condition's farmers. There were no incidences of pests and diseases during the research but to protect the bird damage mesh bags were used.

The following parameters were evaluated within the scope of the study: plant height $(\mathrm{cm})$, head diameter $(\mathrm{cm})$, thousand seeds weight $(\mathrm{g})$, seed yield per plant $(\mathrm{g})$, hull-kernel ratio (\%), seed yield $(\mathrm{kg} / \mathrm{ha})$ and crude oil rate $(\%)$. Variance analysis was performed on the obtained data according to the random blocks method [7]. The Duncan test was employed to determine the significance of the differences between the trials. All statistical calculations and the variance of data was analysed by MSTATC software [8].

\section{RESULT AND DISCUSSION}

The data regarding plant height of 10 confectionary sunflower genotypes and population were significantly $(\mathrm{P}<0.01)$ different both research years, as shown in Table 3 . The genotypes Inegöl $(161.33 \mathrm{~cm})$ and ÇRZ-13-7 $(160.03 \mathrm{~cm})$ produced the maximum plant height in first year and 
ÇRZ-13-6 $(154.27 \mathrm{~cm})$ was higher in second year. The differences in plant height may also be attributed to the genetic potential of genotypes and the other prevailing environmental conditions. Mean plant height of $2015(150.28 \mathrm{~cm})$ was higher than the plant height of 2016 $(144.79 \mathrm{~cm})($ Table 3$)$. This kind of differences may be resulted from climate, environmental conditions, and cultural practices. Sufficient precipitation, temperature rises, lighting intensity, daylight duration, latitude and longer photo periods during the growing seasons may increase plant heights [9]. Montemurro, De Giorgio [10] indicated that high precipitations improved early vegetative development of sunflower and environmental conditions had positive impacts on plant growth and development.

Head diameter data of 10 confectionary sunflower genotypes and populations were significantly $(\mathrm{P}<0.05)$ different in the first year of research. The higher head diameter was obtained from Çiğdem-1 cultivar $(20.35 \mathrm{~cm})$ and lowest head diameter was from ÇRZ-13-7 genotype (16.64 $\mathrm{cm}$ ) (Table 3). Second year, head diameters of genotypes were very close to each other due to the higher temperature and less precipitation comparison of first year (Table 2). Coşge and Ulukan [11] reported that head diameter as the most significant yield parameter and positive effects of head diameter on seed yield. However, Kaya, Evci [12]mention that seed yield increases until a head diameter of $24 \mathrm{~cm}$ and decreased seed yields over size of $24 \mathrm{~cm}$ head diameter.

Table 3. Some agronomic traits of confectionary sunflower cultivars grown in 2015 and 2016

\begin{tabular}{|c|c|c|c|c|c|c|c|c|}
\hline \multirow{2}{*}{$\begin{array}{l}\text { Analysis of } \\
\text { Variance }\end{array}$} & \multicolumn{2}{|c|}{ Plant Height $(\mathrm{cm})$} & \multicolumn{2}{|c|}{$\begin{array}{l}\text { Head diameter } \\
(\mathrm{cm})\end{array}$} & \multicolumn{2}{|c|}{$\begin{array}{l}\text { Thousand } \quad \text { seed } \\
\text { weight }(\mathrm{g})\end{array}$} & \multicolumn{2}{|c|}{$\begin{array}{l}\text { Seed yield per } \\
\text { plant }(\mathrm{g})\end{array}$} \\
\hline & 2015 & 2016 & 2015 & 2016 & 2015 & 2016 & 2015 & 2016 \\
\hline Replication & 6.873 & 11.132 & 1.973 & 0.327 & 103.273 & 111.016 & 3.368 & 8.095 \\
\hline Cultivars & $130.09^{* *}$ & $93.64 * *$ & $3.44 *$ & $2.35 \mathrm{~ns}$ & $355.03 * *$ & $368.43 * *$ & $311.04 * *$ & $295.65 * *$ \\
\hline Error & 20.76 & 22.812 & 1.357 & 1.606 & 84.172 & 53.582 & 77.725 & 50.528 \\
\hline $\mathrm{CV}$ & $3.03 \%$ & $3.21 \%$ & $6.28 \%$ & $7.19 \%$ & $8.61 \%$ & $7.78 \%$ & $7.78 \%$ & $6.28 \%$ \\
\hline Çiğgdem-1 & $148.90 \mathrm{bc}$ & $141.90 \mathrm{c}$ & $20.35 \mathrm{a}$ & 19.17 & $120.61 \mathrm{ab}$ & $105.21 \mathrm{abc}$ & $122.74 a$ & $109.92 \mathrm{ab}$ \\
\hline ÇRZ 13-6 & $152.27 \mathrm{ab}$ & $154.27 \mathrm{a}$ & $18.69 \mathrm{abc}$ & 17.70 & 97.91cd & $78.53 \mathrm{e}$ & $95.39 \mathrm{c}$ & $90.40 \mathrm{c}$ \\
\hline CRZ 13-9 & $141.33 \mathrm{c}$ & $139.87 \mathrm{c}$ & $19.35 \mathrm{abc}$ & 17.41 & $98.78 \mathrm{~cd}$ & $96.75 \mathrm{ad}$ & $119.57 \mathrm{ab}$ & $117.27 \mathrm{a}$ \\
\hline ÇRZ 13-7 & $160.03 a$ & $153.37 \mathrm{ab}$ & $16.64 d$ & 16.25 & $93.95 \mathrm{~d}$ & $81.70 \mathrm{de}$ & $100.91 b c$ & $92.90 \mathrm{c}$ \\
\hline Elbistan & $149.23 b c$ & $139.83 \mathrm{c}$ & $19.74 a b$ & 18.80 & $125.93 \mathrm{a}$ & $107.80 \mathrm{ab}$ & $122.71 \mathrm{a}$ & $118.92 \mathrm{a}$ \\
\hline Hamit & $144.27 b c$ & $143.17 b c$ & $18.62 \mathrm{ad}$ & 18.12 & 117.00abc & $110.20 \mathrm{a}$ & $127.51 \mathrm{a}$ & $113.32 \mathrm{ab}$ \\
\hline
\end{tabular}


International Journal of Agriculture, Environment and Bioresearch

Vol. 06, No. 01; 2021

ISSN: $2456-8643$

\begin{tabular}{|l|l|l|l|l|l|l|l|l|}
\hline İnegöl & $161.33 \mathrm{a}$ & $144.90 \mathrm{abc}$ & $17.69 \mathrm{~cd}$ & 16.65 & $98.35 \mathrm{~cd}$ & $83.87 \mathrm{de}$ & $108.40 \mathrm{abc}$ & $97.21 \mathrm{bc}$ \\
\hline $\begin{array}{l}\text { PALANCI- } \\
1\end{array}$ & $143.67 \mathrm{bc}$ & $137.60 \mathrm{c}$ & $17.96 \mathrm{bcd}$ & 17.35 & $104.33 \mathrm{bcd}$ & $90.57 \mathrm{cde}$ & $110.92 \mathrm{abc}$ & $99.97 \mathrm{bc}$ \\
\hline ÇRZ 13-4 & $149.23 \mathrm{bc}$ & $146.22 \mathrm{abc}$ & $18.41 \mathrm{ad}$ & 17.54 & $102.46 \mathrm{bcd}$ & $90.80 \mathrm{be}$ & $110.33 \mathrm{abc}$ & $104.40 \mathrm{abc}$ \\
\hline ÇRZ 13-10 & $152.52 \mathrm{ab}$ & $146.79 \mathrm{abc}$ & $18.07 \mathrm{bcd}$ & 17.39 & $106.51 \mathrm{ad}$ & $96.04 \mathrm{ad}$ & $114.61 \mathrm{abc}$ & $106.89 \mathrm{abc}$ \\
\hline Mean & 150.28 & 144.79 & 18.55 & 17.64 & 106.58 & 94.15 & 113.31 & 105.12 \\
\hline LSD & 10.71 & 11.07 & 1.998 & & 21.56 & 17.20 & 20.72 & 16.71 \\
\hline
\end{tabular}

Regarding thousand seed weight, genotypes were significantly $(\mathrm{P}<0.01)$ different and ranged from $78.53 \mathrm{~g}$ to $125.93 \mathrm{~g}$ in the research. First year Elbistan (125.93 g) and second year Hamit $(110.20 \mathrm{~g})$ were highest thousand seed weight and lowest in 2015 was ÇRZ 13-7 (93.95 g) and ÇRZ 13-6 (78.53 g) was in 2016. Genetics of the cultivars and environmental conditions wit temperature and water stress were effective in differences in thousand seed weights of the cultivars. Westgate [13]reported that the main reason for seed weight reduction is a decrease in grain filling period due to stress. Since our research area was under rainfed agriculture conditions temperature and water stress are important factors on seed weight.

Seed yield per plant data of 10 confectionary sunflower genotypes and populations were significantly $(\mathrm{P}<0.01)$ different. The higher seed yield per plant was obtained from Hamit $(127.51 \mathrm{~g})$ and Elbistan (118.92 gr) population and lowest was $95.39 \mathrm{~g}$ and $90.40 \mathrm{~g}$ from ÇRZ13-6 genotype in 2015 and 2016 respectively (Table 3). According to genotypes and years mean of seed yield per plant was higher in the 2015 growing season and the differences of seed yield per plant was more than $8 \mathrm{~g} / \mathrm{plant}$. It means that about $35000 \mathrm{plant} / \mathrm{ha} \times \mathrm{gg}=286 \mathrm{~kg}$ ha- 1 seed loses. The main reason for this difference was the distinction among climatic conditions of growing seasons. During 2016, the dry and warmer condition was received than 2015. Especially, because of the insufficient rainfall after May and high temperatures probably reduced the seed yield.

Hull ratio of seeds data of 10 confectionary sunflower genotypes and populations were significantly $(\mathrm{P}<0.01)$ different. The higher hull ratio was obtained from Elbistan $(51.34 \%$ and $54.37 \%$ ) population and lowest was $43.71 \%$ and $45.85 \%$ from Palanc1- 1 cultivars in 2015 and 2016 respectively (Table 4). According to genotypes and years mean of hull ratio was higher in the 2016 growing season and the differences was about 3\%. The main reason for this difference was the distinction among climatic conditions of seed filling period. Especially, because of the insufficient rainfall after July and higher temperatures probably reduced the seed filling.

Table 4. Some agronomic traits of confectionary sunflower cultivars grown in 2015 and 2016

\begin{tabular}{|l|l|l|l|}
\hline Analysis of & Seed hull rate (\%) & Seed yield $\left(\mathrm{kg} \mathrm{ha}^{-1}\right)$ & Crude oil rate (\%) \\
\hline
\end{tabular}


International Journal of Agriculture, Environment and Bioresearch

Vol. 06, No. 01; 2021

ISSN: $2456-8643$

\begin{tabular}{|l|l|l|l|l|l|l|}
\hline Variance & 2015 & 2016 & 2015 & 2016 & 2015 & 2016 \\
\hline Replication & 2.291 & 1.47 & 46428.41 & 52473.32 & 0.714 & 0.809 \\
\hline FactorA & $17.86^{* *}$ & $20.82^{* *}$ & $279556.3^{* *}$ & $386949.09^{* *}$ & $8.67^{* *}$ & $7.93^{* *}$ \\
\hline Error & 3.069 & 4.754 & 46092.07 & 50738.34 & 1.222 & 1.568 \\
\hline CV & $3.70 \%$ & $4.63 \%$ & $6.45 \%$ & $7.70 \%$ & $3.58 \%$ & $3.94 \%$ \\
\hline Çiğdem-1 & $47.01 \mathrm{bcd}$ & $50.24 \mathrm{abc}$ & $3791.39 \mathrm{a}$ & $3354.09 \mathrm{a}$ & $28.48 \mathrm{~d}$ & $28.87 \mathrm{~d}$ \\
\hline ÇRZ 13-6 & $45.25 \mathrm{~cd}$ & $48.41 \mathrm{bc}$ & $2993.38 \mathrm{~d}$ & $2535.03 \mathrm{~b}$ & $32.14 \mathrm{ab}$ & $32.29 \mathrm{abc}$ \\
\hline ÇRZ 13-9 & $47.48 \mathrm{ad}$ & $49.40 \mathrm{abc}$ & $3127.59 \mathrm{~cd}$ & $2948.00 \mathrm{ab}$ & $32.16 \mathrm{ab}$ & $33.40 \mathrm{ab}$ \\
\hline ÇRZ 13-7 & $45.00 \mathrm{~cd}$ & $48.81 \mathrm{bc}$ & $2929.50 \mathrm{~d}$ & $2438.54 \mathrm{~b}$ & $33.67 \mathrm{a}$ & $34.24 \mathrm{a}$ \\
\hline Elbistan & $51.34 \mathrm{a}$ & $54.37 \mathrm{a}$ & $3771.75 \mathrm{ab}$ & $3382.12 \mathrm{a}$ & $28.57 \mathrm{~d}$ & $30.49 \mathrm{bcd}$ \\
\hline Hamit & $50.84 \mathrm{ab}$ & $54.19 \mathrm{a}$ & $3617.77 \mathrm{abc}$ & $3418.66 \mathrm{a}$ & $29.28 \mathrm{~cd}$ & $30.19 \mathrm{~cd}$ \\
\hline İnegö1 & $48.37 \mathrm{abc}$ & $51.03 \mathrm{ab}$ & $3312.49 \mathrm{ad}$ & $2602.45 \mathrm{~b}$ & $30.68 \mathrm{bcd}$ & $31.36 \mathrm{ad}$ \\
\hline PALANCI-1 & $43.71 \mathrm{~d}$ & $45.85 \mathrm{c}$ & $3271.18 \mathrm{bcd}$ & $2810.49 \mathrm{~b}$ & $30.86 \mathrm{bcd}$ & $31.76 \mathrm{ad}$ \\
\hline ÇRZ 13-4 & $46.57 \mathrm{~cd}$ & $48.87 \mathrm{bc}$ & $3162.67 \mathrm{~cd}$ & $2797.16 \mathrm{~b}$ & $31.99 \mathrm{ab}$ & $33.09 \mathrm{abc}$ \\
\hline ÇRZ 13-10 & $48.06 \mathrm{abc}$ & $51.65 \mathrm{ab}$ & $3291.58 \mathrm{ad}$ & $2961.48 \mathrm{ab}$ & $31.18 \mathrm{abc}$ & $32.29 \mathrm{abc}$ \\
\hline Mean & 47.36 & 50.28 & 3326.93 & 2924.80 & 30.90 & 31,80 \\
\hline LSD & 4.12 & 5.13 & 504.6 & 529.4 & 2.60 & 2.94 \\
\hline
\end{tabular}

In this research, differences of genotypes had significantly $(\mathrm{P}<0.01)$ effected seed yield. The highest seed yield (3791.39 $\left.\mathrm{kg} \mathrm{ha}^{-1}\right)$ was determined from Çiğdem-1 cultivar in 2015 and Hamit population (3418.66 kg ha-1) in 2016, the lowest seed yield (2929.50 and $2438.54 \mathrm{~kg} \mathrm{ha}^{-1}$ ) was obtained from the ÇRZ 13-7 genotype. Generally, 2016 research year was lowest seed yield due to the less rainfall and warmer period after May to maturity stage. In similar studies conducted with confectionary sunflower was reported seed yield between from $2166.60 \mathrm{~kg} \mathrm{ha}^{-1}$ to 5730.20 $\mathrm{kg} \mathrm{ha}^{-1}[2,4,5,14]$ In this study lowest seed yield result was over researchers' lowest yield but highest seed yield of this study lower than researchers' highest yield results. Since our research area was under rainfed agriculture conditions temperature and water stress especially insufficient rainfall after flowering stage have negative effect on seed yield.

In the study, the crude oil ratios varied between $28.48 \%$ and $34.24 \%$. Differences in crude oil ratios between genotypes were statistically significant $(\mathrm{P}<0.01)$. The highest crude oil ratio $(33.67$ 
and 34.24\%) was determined from ÇRZ 13-7 cultivar in 2015 and 2016, the lowest crude oil ratio (28.48 and $28.87 \%$ ) was obtained from the Çiğdem-1 cultivar. Confectionary sunflower, unlike oil sunflower high crude oil content is not desirable. Crude oil ratio is a character that affected by many environmental and genotypic factors. Jocic, Miladinovic [15]stated that the crude oil ratio in confectionary sunflower varieties should be below $40 \%$.

\section{CONCLUSION}

Differences in climate and environmental factors of the experimental years significantly affected the investigated traits of confectionary sunflower genotypes. While rainy growing season of 2015 had positive effects on yield and yield parameters, negative effects of less rainfall and warmer climate condition was determined in 2016 comparing the yield and yield parameters results of genotypes. Especially seed filling period, because of the insufficient rainfall and warmer weather condition after June, probably negatively affected the yield parameters such as table diameter, thousand seed weight, seed yield per plant etc. and resulted decrease in seed yield. Rainfed agriculture condition especially in semi-arid climate zone, rainfall in growing period is important climate factor on seed yield. After flowering stage dry and hotter climate condition reduce seed yield and seed quality. Genotypes have important role with under stress conditions. In this study it was determined that genetic capability of variety under stress condition had important role on sufficient seed yield. In this study new cultivar Çiğdem-1 had highest seed yield in wet season but Hamit, Elbistan and Çiğdem-1 highest in dry and hotter condition. When stress conditions increase, local populations can be better in seed yield. So, breeding research have important for generate new generation for dry and hotter climate condition with use of local populations.

\section{REFERENCES}

[1] R.B. Duane, "Sunflower production," NDSU Extension Service, ND Agricultural Experiment Station, North Dakota State University, America, 2007.

[2] M. Sincik, and A.T. Goksoy, "Investigation of correlation between traits and path analysis of confectionary sunflower genotypes," Notulae Botanicae Horti Agrobotanici Cluj-Napoca, vol. 42, no. 1, pp. 227-231, 2014.

[3] Y.E.C. Sağlam, "Bazı çerezlik ayçiçeği (Helianthus annuus L.) çeşitlerinin tekirdağ koşullarında verim ve verim unsurları," Tekirdă̆ Ziraat Fakültesi Dergisi, vol. 2, no. 3, pp. 221-227, 2005.

[4] V. Pekcan, E. Goksel, İ.M. Yİlmaz, and K. Yalcin, "Developing confectionery sunflower hybrids and determination of their yield performances in different environmental conditions," Ekin Journal of Crop Breeding and Genetics, vol. 1, no. 2, pp. 47-55, 2015.

[5] G. Yilmaz, A. Kinay, E. Turan, and Ş. Dökülen, "Tokat şartlarında farklı çerezlik ayçiçeği (Helianthus annuus L.) genotiplerinin performanslarının belirlenmesi," Tarla Bitkileri Merkez Araştırma Enstitüsü Dergisi, vol. 26, no. 2, pp. 161-169, 2017.

[6] B. Kacar, Bitki ve topră̆ın kimyasal analizleri, Ankara Ünİversitesi Ziraat Fakültesi Eğitim, Araştırma ve Geliştirme Vakfı, 1994. 
[7] O. Düzgüneş, T. Kesici, O. Kavuncu, and F. Gürbüz, "Araştırma ve deneme metodları (İstatistik Metodları-II)," Ankara Üniversitesi Ziraat Fakültesi Yayınları, vol. 1021, pp. $295,1987$.

[8] D. Russell, "MSTAT-C package programme," Crop and Soil Science Department, Michigan State University, USA, 1986.

[9] Y. Kaya, Genotype and environment interactions with physiological maturity of sunflower (Helianthus annuus L.) hybrids in western Nebraska, University of

Nebraska, Lincoin, NE. USA., 1998.

[10]F. Montemurro, D. De Giorgio, F. Fornaro, E. Scalcione, and C. Vitti, "Influence of climatic conditions on yields, $\mathbf{N}$ uptake and efficiency in sunflower," Italian Journal of Agrometeorology, vol. 2, pp. 28-34, 2007.

[11]B. Coşge, and H. Ulukan, "Ayçiçeği (Helianthus annuus L.) Yetiştiriciliğimizde Çeşit ve Ekim Zamanı," Süleyman Demirel Üniversitesi Fen Bilimleri Enstitüsü Dergisi, vol. 9, no. 3, pp. 43-48, 2005.

[12] Y. Kaya, G. Evci, V. Pekcan, T. Gücer, and M. Yilmaz, "The determination relationships between oil yield and some yield traits in sunflower," Tarim Bilimleri Dergisi, vol. 15, no. 4, pp. 310-318, 2009.

[13] M.E. Westgate, "Water status and development of the maize endosperm and embryo during drought," Crop science, vol. 34, no. 1, pp. 76-83, 1994.

[14] A.Ş. Tan, "Characterization of Confectionary Sunflower (Helianthus annuus L.) Genetic resources of denizli and erzurum provinces," Anadolu Ege Tarımsal Araştırma Enstitüsü Dergisi, vol. 23, no. 1, pp. 5-11, 2013.

[15]S. Jocic, D. Miladinovic, and Y. Kaya, "Breeding and genetics of sunflower" in Sunflower, pp. 1-25, Elsevier, 2015. 